\title{
Fraude en accountant in het huidige tijdsbeeld
}

\section{André Bindenga}

SAMENVATTING Accountants kunnen niet langer de kritiek van het maatschappelijk verkeer pareren door te wijzen op door henzelf ontwikkelde theorieën over de grenzen van de accountantscontrole. In dit artikel worden voorstellen gedaan om de verwachtingskloof te overbruggen.

\section{Inleiding}

Naar aanleiding van recente gebeurtenissen is het gewenst het onderwerp van de relatie tussen fraude en accountant opnieuw aan de orde te stellen. In het verleden is in de vakliteratuur vrij uitputtend over fraude geschreven en in internationale en nationale richtlijnen wordt aan fraude uitgebreid aandacht geschonken. Blijkbaar bestaan er echter nog steeds verschillen van opvatting tussen het publiek en het accountantsberoep over de verantwoordelijkheid van de accountant voor fraude.

In de tweede paragraaf van dit artikel zal ik kort ingaan op het begrip fraude en vervolgens in de derde paragraaf de beroepsopvattingen weergeven. In de vierde paragraaf leg ik de relatie met het publiek. In de vijfde paragraaf zal ik ten slotte een voorstel formuleren om de verschillen van mening te overbruggen.

\section{Het begrip fraude}

Het is niet zo gemakkelijk een definiëring van het begrip fraude te geven, waarover iedereen het direct eens zal zijn. In het algemeen heeft fraude een nogal ruime betekenis. Zodra sprake is van bedrog, neemt

Prof. Dr. A.J. Bindenga RA is oud-voorzitter van Ernst \& Young en oud-voorzitter van het Koninklijk NivRA. Hij is thans nog partner van Ernst \& Young en hoogleraar accountancy aan de Erasmus Universiteit Rotterdam. men al snel het begrip fraude in de mond. Bij de accountantscontrole wordt met een beperkter begrip gewerkt.

In de monografie van Brugge (1965), een studie die al geruime tijd geleden over dit verschijnsel is verschenen, wordt onder fraude verstaan:

'Het zichzelf dan wel anderen wederrechtelijk bevoordelen en wel met behulp van bedrieglijke middelen, door misbruik van het in dienstbetrekking geschonken vertrouwen.'

Deze definitie is wel erg beperkt. Het betreft alleen een fraudeur in dienstbetrekking en bovendien moet er kennelijk misbruik zijn van geschonken vertrouwen. Er zijn vele voorbeelden van fraude door personen aan wie geen enkel vertrouwen is geschonken.

De begripsomschrijving die thans veel wordt gehanteerd $^{1}$, is:

'Het opzettelijk door één of meer personen vervalsen, weglaten, toevoegen of verwijderen van gegevens teneinde waarden aan een huishouding op onrechtmatige wijze te onttrekken of te doen toevloeien.'

Ik merk op dat bovenstaande definitie in beroepskringen wordt uitgelegd in relatie tot de jaarrekening van de huishouding. De opzettelijke handelingen dienen te resulteren in onjuiste informatie in de jaarrekening $^{3}$. De oude definitie van Brugge was wat dit betreft wel weer ruimer, aangezien de relatie met de jaarrekening ontbrak. Reeds nu wijs ik erop, dat hier in feite sprake is van het verschijnsel materialiteit. Ik kom hier in de tweede paragraaf op terug, maar de oorzaak van de discrepantie tussen de opvattingen van het publiek en het accountantsberoep ligt vooral op dit terrein.

Het publiek hanteert geen definitie, maar vindt dat er sprake is van fraude, indien personen in het zakelijk verkeer bedrog plegen of feiten en gebeurtenissen vervalsen. Dit hoeft geenszins te leiden tot onjuiste informatie in de jaarrekening. $\mathrm{Nu}$ zullen accountants waarschijnlijk niet ontkennen dat bedrog en vervalsing vormen van fraude zijn, maar alleen als een en 
ander van zekere omvang is, leidt dit naar de opvatting van accountants tot onjuiste informatie in de jaarrekening en is er alleen dan sprake van fraude in vaktechnische zin.

\section{Fraude en de accountant}

Over de mogelijkheden om fraude door middel van accountantscontrole op te sporen, wordt binnen het beroep genuanceerd gedacht. Zonder aanspraak te maken op volledigheid geef ik een samenvatting. In het algemeen onderscheidt men twee soorten fraude:

a Fraudes die hun sporen nalaten in de gecontroleerde organisatie, met name in administratieve vastleggingen.

b Fraudes die hun sporen niet nalaten in de gecontroleerde organisatie, met name in administratieve vastleggingen.

\section{Ad a}

Bij de huidige opzet van de accountantscontrole wordt een belangrijke functie toegekend aan risicoinschattingen. Indien deze ertoe leiden, dat er risico's van fraude aanwezig zijn, zal de accountant er bij zijn controlewerkzaamheden rekening mee houden. Vele accountants trekken hieruit de conclusie dat fraudes die materieel van omvang zijn, bij een goed uitgevoerde accountantscontrole moeten worden vastgesteld. Niet-materiële fraudes kunnen echter niet altijd worden geconstateerd.

\section{Ad b}

De hier bedoelde fraudes zijn een gevolg van zogenaamde samenspanning dan wel fraudes waaraan de hoogste leiding medewerkt. In de accountantscontrole zijn deze fraudes moeilijk te ontdekken. Soms zijn er aanwijzingen voor, soms in het geheel niet. Aanwijzingen kunnen bijvoorbeeld transacties zijn die zonder rationele gronden geheim worden gehouden voor lagere niveaus in de organisatie ${ }^{4}$.

Binnen het beroep is de algemene opvatting dat de controle van de jaarrekening niet gericht is op het ontdekken van fraude. Voor een fraudeonderzoek dienen namelijk detailcontroles en inventarisaties te worden gepland in een aanzienlijk grotere omvang dan bij de algemene controle nodig is ${ }^{5}$.

In het kader van dit artikel is het van belang vast te stellen welke werkzaamheden een speciaal fraudeonderzoek omvatten.

In het algemeen kan worden gesteld, dat voor een fraudeonderzoek kennis nodig is op het gebied van het civiele recht en het bewijsrecht, het interviewen van betrokkenen en de wijze van rapporteren. Dit behoort niet tot de normale deskundigheid van de accountant. In de uitvoering van een fraudeonderzoek kan meestal niet worden volstaan met partiële waarnemingen, al dan niet in de vorm van steekproeven. Het onderzoek zal integraal op detailniveau geschieden. De wijze waarop dit onderzoek plaatsvindt, is een taak van gespecialiseerde accountants of onderzoekbureaus.

De conclusie uit het vorenstaande kan geen andere zijn dan dat het uitvoeren van een accountantscontrole en het opsporen van fraude twee verschillende bezigheden zijn. Het is niet de taak van de accountant die de getrouwheid van de jaarrekening vaststelt, fraude te allen tijde te ontdekken.

\section{Fraude en het publiek}

De opdrachten die openbare accountants uitvoeren, zijn verschillend van aard. De meest voorkomende opdracht is de controle van de jaarrekening van een organisatie. Hoewel de accountant een dergelijke opdracht meestal krijgt van het bestuur of het toezichthoudend orgaan van een organisatie, is het algemeen erkend, dat de accountant zijn functie vervult ten behoeve van een veel grotere kring van belanghebbenden. In het verleden werd daarom wel gezegd dat de primaire functie van de openbare accountant die is van vertrouwensman van het maatschappelijk verkeer ${ }^{6}$. In internationaal verband wordt er in dit kader op gewezen, dat de openbare accountant werkt in 'the interest of the public'7. In dit verband wordt wel gesteld, dat de accountant tegemoet moet komen aan de verwachtingen van het financieel-economisch verkeer. Het is interessant in relatie hiertoe terug te grijpen op een onderzoek uit $1987^{8}$, waarin de opvattingen over accountants zijn onderzocht. Zoals uit de vorige paragraaf bleek, wordt over de verantwoordelijkheid van accountants ten aanzien van fraude genuanceerd gedacht. De opinies van derden zijn daarom van belang. Uit het genoemde onderzoek bleek dat vrijwel iedereen van mening was, dat accountantscontrole mede ten doel heeft fraude te voorkomen of te ontdekken. Er bestond destijds dus een belangrijke kloof tussen de verwachtingen van het publiek en de mening van accountants. Over het effect in de praktijk bleek uit het onderzoek dat niet iedereen van mening was, dat de accountant aan deze verwachting voldeed.

Vijftien jaar na het onderzoek kan worden vastgesteld, dat uit de discussies rond de 'bouwfraude' blijkt dat de situatie niet veranderd is. Het publiek en ook 
de politiek is blijkbaar van mening, dat de accountantscontrole fraude aan het licht dient te brengen, onafhankelijk van het feit of de fraude materieel is en of de fraude invloed heeft op de informatie in de jaarrekening.

De verwachtingskloof met betrekking tot fraude is breed aanwezig.

\section{Hoe nu verder?}

Het accountantsberoep ligt onder vuur, onder meer als wordt gesproken over fraude. In het huidige tijdsbeeld lijkt het mij niet aanvaardbaar, dat accountants geen antwoord geven op vragen zoals die uit de maatschappij aan hen worden gesteld. Accountants kunnen niet langer de kritiek van het maatschappelijk verkeer pareren door te wijzen op door henzelf ontwikkelde theorieën over de grenzen van de accountantscontrole.

Indien het maatschappelijk verkeer eist dat openbare accountants in hun opzet van de accountantscontrole rekening houden met de wens fraude op te sporen, dan zullen zij hun controlemethodieken dienen aan te passen. Zij zullen zich niet alleen meer moeten richten op de informatie die de jaarrekening verschaft, maar hun onderzoek breder moeten uitvoeren. Vanzelfsprekend kan dit niet zonder slag of stoot.

In de eerste plaats zal de opdracht tot accountantscontrole anders moeten worden geformuleerd. Naast de opdracht tot de controle van de jaarrekening zal opdracht moeten worden gegeven tot het verrichten van overeengekomen specifieke werkzaamheden. Het is immers duidelijk dat een onderzoek naar fraude diepgaander is dan de algemene controle. Bovendien zullen afspraken moeten worden gemaakt over de wijze van rapportering. Naast de accountantsverklaring bij de jaarrekening zal een rapportage moeten worden samengesteld die ten behoeve van buitenstaanders kan worden gebruikt. De huidige regels die gelden voor een rapport van feitelijke bevindingen ${ }^{9}$ zijn hiervoor niet voldoende.

In de tweede plaats zullen in het team dat de accountantscontrole uitvoert, deskundigen moeten worden opgenomen, die gespecialiseerd zijn. De vraag is of dit forensische accountants zijn of rechercheurs/nietaccountants.

In de derde plaats zal moeten worden nagegaan of de inzet van specialisten zal leiden tot een andere aanpak van de accountantscontrole in het algemeen. Het is namelijk de vraag of de risicoanalysebenadering nog wel past, indien tegelijkertijd gedetailleerde onderzoeken plaatsvinden, gericht op de opsporing van fraude. Wellicht dat daardoor de gehele controle veel meer gegevensgericht gaat worden dan thans gebruikelijk is.

Ten slotte is het onvermijdelijk dat er invloed zal uitgaan op de kosten van de accountantscontrole. Het is niet onaannemelijk dat de kosten hoger zullen worden.

Naast vorenstaande kanttekeningen zijn er ongetwijfeld nog vele andere opmerkingen te maken. Het belangrijkste uitgangspunt is dat accountants moeten voldoen aan gerechtvaardigde verwachtingen van het maatschappelijk verkeer. Als het mogelijk is dat aan deze verwachtingen kan worden tegemoet gekomen, zullen accountants zich bewust moeten zijn van hun primaire functie als vertrouwensman van het maatschappelijk verkeer.

\section{Literatuur:}

Brugge, W.G., (1965), Het fraudeprobleem, Amsterdam/Brussel.

Frielink, A.B. en J.C.E. van Kollenburg, (1999), Leerboek Accountantscontrole, deel 5 , Houten

Frielink, A.B., (1981), Het verschijnsel fraude en de taak van de accountant, in: Fraude, automatisering en accountant, Limperg Instituut (redactie), Amsterdam.

Koninklijk NIVRA, (1994), Richtlijnen voor de Accountantscontrole, Verordening op fraudemelding vastgesteld in de bijeenkomst van de ledenvergadering op 21 juni 1994, afgekondigd in de Nederlandse Staatscourant van 15 september 1994, nr. 177, laatstelijk gewijzigd in de bijeenkomst van de ledenvergadering op 30 november 1994, Staatscourant 1995, nr. 48.

Limperg Instituut, (1987), Opvattingen over accountants, Amsterdam.

Limperg, Th., (1965), Verzameld Werk, deel 6, Deventer.

Panel on Audit Effectiveness, (2000), Report and Recommendations, zie: www.pobauditpanel.org.

\section{Noten}

1 Verordening op de fraudemelding, artikel 1 (1994).

3 Richtlijnen voor de accountantscontrole, paragraaf 240 (2000).

4 A.B. Frielink, Het verschijnsel fraude en de taak van de accountant (Amsterdam, 1981).

5 Leerboek Accountantscontrole, deel 5 (Houten, 1999).

6 Men raadplege de geschriften van Th. Limperg, met name Verzameld Werk, deel 6 (Deventer, 1965).

7 Panel on Audit Effectiveness (2000)

8 Opvattingen over accountants (Limperg Instituut, 1987).

9 Richtlijnen voor de accountantcontrole, paragraaf 920 (2000). 